_3_6/77.pdf (дата звернення: 3.11.2019).

11. Costanza, R., d'Arge, R., de Groot, R., Farber, S., Grasso, M., Hannon, B. van den Belt, M.. The value of the world's ecosystem services and natural capital. Nature, 387,1997. P.253-260.

12. Costanza, R., Cumberland, J. H., Daly, H., Goodland, R., Norgaard, R. B., Kubiszewski, I., et al. . An introduction to ecological economics. Boca Raton, FL: CRC Press.:2014. URL: http://library.uniteddiversity.coop/Measuring _Progress_and_Eco_Footprinting/An_Introduction_to_Ecological_Economics.pdf (дата звернення: 3.11.2019).

13. Peskin, H. M. A national accounting framework for environmental assets. Journal of Environmental Economics and Management, 1976. №2, p. 255-262.

14. Екосистемні послуги Голосіївського лісу. URL: http://uacrisis.org/ua/66526golosiyivskyj-park (дата звернення: 3.11.2019).

15. Helm Dieter. Natural capital: assets, systems, and policies. OXFORD REVIEW OF ECONOMIC POLICY. 2019. T: 35. № 1. P. 1-13.

"УДК 332.12(477)

Забедюк М.С., к.е.н., доцент

Луцький національний технічний університет

\title{
ТЕОРЕТИЧНІ АСПЕКТИ УПРАВЛІННЯ ОБОРОТНИМ КАПІТАЛОМ ПІДПРИЕМСТВА
}

У статті висвітлено сутність та основні завдання управління оборотним капіталом підприємства. Розглянуто принципи та функції управління оборотним капіталом підприємства. Виокремлено чинники, які спричиняють негативний вплив на формування та використання оборотного капіталу підприємства.

Ключові слова: оборотний капітал, управління оборотним капіталом, структура капіталу, підприємство.

\section{Zabedyuk M. \\ THEORETICAL ASPECTS OF CURRENT ASSETS MANAGEMENT OF THE ENTERPRISE}

The article covers the essence and main tasks of managing current assets of the enterprise. In today's business environment, the activity of enterprises is closely linked to the formation and use of current assets, which has a special place in the capital structure of the enterprise. At the same time, the continuity of the production and sale of products, liquidity of the enterprise, its solvency and profitability depend on the quality

\footnotetext{
* Забедюк М.C.
} 
of management of current assets. Current assets management is about finding effective forms of its financing, optimizing its volume, improving its structure and increasing its efficiency.

Current assets management is aimed at solving such tasks as ensuring the necessary amount of current assets in order to maintain current solvency, optimization of current assets structure to ensure liquidity ratios, search for sources of current assets financing, taking into account the conditions for ensuring the financial stability of the entity.

It should be noted that current assets management is based on such principles, as interconnectedness, timeliness, coordination, continuity, optimality and rationality. The application of all these principles in combination will ensure the effective formation and implementation of the policy of current assets management of the enterprise.

The main functions of current assets management are analytical, which is to ensure the constant analysis of current assets and its elements; stabilizing, which is to take measures to ensure a sufficient level of liquidity and solvency of the enterprise; control, which consists in the formation of a system of integrated control over the volume of current assets and the state of liquidity and solvency of the enterprise.

The factors that cause a negative impact on the formation and use of the current assets of the enterprise are defined.

Key words: current assets, current assets management, capital structure, enterprise.

\section{Забедюк М.С.}

\section{ТЕОРЕТИЧЕСКИЕ АСПЕКТЫ УПРАВЛЕНИЯ ОБОРОТНЫМ КАПИТАЛОМ ПРЕДПРИЯТИЯ}

В статье освещены сущность и основные задачи управления оборотным капиталом предприятия. Рассмотрены принципы и функции управления оборотным капиталом предприятия. Выделены факторы, оказывающие негативное влияние на формирование и использование оборотного капитала предприятия.

Ключевые слова: оборотный капитал, управление оборотным капиталом, структура капитала, предприятие.

Постановка проблеми у загальному вигляді та ії̈ зв'язок 3 важливими науковими та практичними завданнями. В сучасних умовах господарювання діяльність підприємств тісно пов'язана 3 формуванням і використанням оборотного капіталу, якому належить особливе місце у структурі капіталу підприємства. При цьому, від якості управління оборотним капіталом залежить безперервність процесу виробництва та реалізації продукції, ліквідність підприємства, його платоспроможність і рентабельність.

Управління оборотним капіталом полягає в пошуку ефективних форм його фінансування, оптимізації обсягу, удосконаленні 
структури та підвищенні ефективності використання [1]. Відтак, управління оборотним капіталом $є$ важливою частиною забезпечення ефективної діяльності підприємств, оскільки від точності розрахунку потреби в оборотному капіталі та ефективності його використання залежить підвищення показників обсягів виробництва, кредитоспроможність та інвестиційна привабливість підприємства.

Аналіз останніх досліджень, у яких започатковано вирішення проблеми. Дослідженням проблем формування та використання оборотного капіталу підприємств займалися такі вчені - економісти як І.А Бланк, Л.О. Болтянська, О.С. Бондаренко, М.В. Володькіна, Т.А. Денисенко, С.М. Жукевич, Т.В. Кравченко, В.В. Краснова, Л.О. Кустріч, В.Г. Маргасова, Л.В. Пельтек, Н.Ю. Соломіна, Н.M. Суліма, О.С. Чорна та інші. Не зважаючи на значну кількість доробок з даної тематики глибшого вивчення потребують проблеми вдосконалення управління оборотним капіталом підприємства.

Цілі статті. Метою статті є дослідження теоретичних аспектів управління оборотним капіталом підприємства.

Виклад основного матеріалу дослідження 3 повним обгрунтуванням отриманих наукових результатів. Управління оборотним капіталом підприємства - це система цілеспрямованої взаємодії між об'єктом (елементами оборотного капіталу і джерелами їх фінансування та економічними відносинами в процесі їх формування та використання) та суб'єктом управління (органами управління підприємства) шляхом реалізації функцій управління із застосуванням комплексу методів, засобів і фінансово-економічних інструментів дослідження і трансформації взаємопов'язаних процесів формування та використання оборотного капіталу і джерел його фінансування за обсягом, складом, структурою з урахуванням дії на нього чисельних факторів внутрішнього і зовнішнього середовища [2].

При цьому, управління оборотним капіталом спрямоване на вирішення таких завдань:

- забезпечення необхідного обсягу оборотного капіталу з метою підтримки поточної платоспроможності;

- оптимізація структури оборотного капіталу задля забезпечення нормативів ліквідності; 
- пошук джерел фінансування оборотного капіталу з врахуванням умов щодо забезпечення фінансової стійкості суб'єкта господарювання;

- контроль обсягу оборотного капіталу та поточних зобов'язань;

- забезпечення ефективності використання оборотного капіталу 3 метою підвищення прибутковості діяльності підприємства.

Слід відмітити, що управління оборотним капіталом грунтується на таких принципах:

1. Взаємопов'язаність - управління оборотним капіталом здійснюється у межах загальної системи управління фінансами підприємств, оскільки будь-яке управлінське рішення прямо або опосередковано впливає на ефективність діяльності підприємств.

2. Своєчасність - управлінські рішення щодо формування та використання кожного елементу оборотного капіталу має прийматися своєчасно та на основі отримання оперативної достовірної інформації.

3. Координація - полягає в забезпеченні узгодженості управлінських рішень щодо функціонування оборотного капіталу з рішеннями щодо поточних зобов'язань.

4. Безперервність - управління оборотним капіталом розглядається як постійний процес, який забезпечує прийняття ряду управлінських рішень, що впливають на ліквідність та платоспроможність підприємства.

5. Оптимальність - управлінські рішення щодо визначення обсягу оборотного капіталу та його елементів спрямовані на формування їх оптимального розміру.

6. Раціональність - усі елементи оборотного капіталу повинні бути раціонально розміщені між стадіями відтворювального процесу суб'єкта господарювання [2, 3].

Відмітимо, що лише застосування усіх зазначених принципів у поєднанні забезпечить ефективність формування та реалізації політики управління оборотним капіталом підприємства.

Основними функціями управління оборотним капіталом є:

- аналітична, яка полягає у забезпеченні проведення постійного аналізу стану оборотного капіталу та його елементів, порівнянні обсягів оборотного капіталу 3 поточними зобов'язаннями, дослідження його динаміки, здійснення аналізу факторів впливу на оборотний капітал; 
"Економічні науки". - Серія "Облік і фінанси". - Випуск 16 (61). - 2019.

- стабілізуюча, що заключається у здійсненні заходів щодо забезпечення достатнього рівень ліквідності та платоспроможності підприємства;

- контрольна - полягає у формуванні системи комплексного контролю за обсягами оборотного капіталу і станом ліквідності та платоспроможності підприємства.

Разом $з$ тим, слід виокремити чинники, які спричиняють негативний вплив на формування та використання оборотного капіталу, а caмe:

- неефективне використання виробничих засобів;

- низький рівень реалізації готової продукції;

- неефективність складу та структури оборотного капіталу;

- незбалансованість дебіторської заборгованості з кредиторською;

- незбалансованість грошових коштів на рахунках у банку чи в касі підприємства;

- обмеження джерел фінансування суб'єктів господарювання;

- недотримання платіжної дисципліни та криза неплатежів;

- інфляційні коливання;

- податковий тиск;

- недосконалість нормативно - правового регулювання.

В свою чергу, неефективність формування та використання оборотного капіталу суб'єктів господарювання в остаточному підсумку може призвести до зменшення прибутковості.

Висновки. Отже, процес управління оборотним капіталом відіграє важливу роль у діяльності суб'єктів господарювання, оскільки саме від прийняття раціональних управлінських рішень щодо формування оборотного капіталу залежить ефективність фінансової діяльності, конкурентоспроможність та платоспроможність підприємства. Більше того, ефективне формування оборотного капіталу суб'єктів господарювання та оптимізація його використання 3 врахуванням внутрішніх та зовнішніх факторів впливу є одним із найважливіших чинників стабілізації економіки в цілому.

1. Кустріч Л.О. Підвищення рівня управління оборотним капіталом. Вісник Хмельницького наиіонального університету. 2010. № 3. С. 103-106.

2. Брушко Г.В. Методологічні основи управління оборотними активами. Культура народов Причерноморья. 2010. № 179. С. 31-33. 
3. Бондаренко О.С. Управління оборотними активами підприємства: автореф. дис. ... канд. економ. наук: 08.04.01. Київ, 2006. 24 с.

*УДК 330.143.1

Зеленко С.В., к.е.н., доцент

Гуляницька Д.В.

Луцький національний технічний університет

\section{ЕКОНОМІКО-МАТЕМАТИЧНЕ МОДЕЛЮВАННЯ ОТРИМАНОГО ПРИБУТКУ ПІДПРИЕМСТВ}

В статті було розглянуто прибуток, як один із найважливіших критеріїв оцінки результативності діяльності суб'єкта господарювання. Також стаття присвячена аналізу теоретичних задач процесу моделювання та розкриттю ключових понять цього процесу. Було розглянуто одні із головних типів моделей. Наведені етапи процесу побудови економетричного моделювання та прогнозування фінансових результатів діяльності підприємства.

Ключові слова: модель, моделювання, прибуток, чистий прибуток, управлінські рішення.

\section{Zelenko S., Hulianytska D. \\ ECONOMIC AND MATHEMATICAL MODELING OF ENTERPRISE PROFIT}

The article considers profit as one of the most important criteria for evaluating the performance of an entity. Also, the article is devoted to the analysis of the theoretical problems of the modeling process and the disclosure of key concepts of this process. One of the main types of models was considered. The stages of the process of econometric modeling and forecasting of financial results of the enterprise activity are presented.

It is revealed that profit, for each business entity, is the central financial category, which reflects the positive financial result of the enterprise's business activity, characterizes the efficiency of utilization of available resources at the enterprise.

The profit of the enterprise is an important category which strengthens the financial condition of the enterprise and at the same time is the primary source of formation of economic stability in a competitive environment. During the research, econometric modeling and forecasting of financial results of the enterprise were carried out, namely: the relationship between net profit and net income from the sale of products (goods, works, services) of the enterprise by econometric analysis methods was investigated.

\footnotetext{
* Зеленко С.В., Гуляницька Д.В.
} 